\title{
Yield of Pennisetum glaucum L. Under Phosphate Source Doses
}

\author{
N. C. Melo ${ }^{1}$, A. R. Fernandes ${ }^{2}$, J. R. Galvão ${ }^{2}$, V. F. Alves Silva ${ }^{2}$, D. R. da Silva ${ }^{2}$ I. M. Viégas ${ }^{2}$, \\ G. S. B. Matos ${ }^{2} \&$ R. S. Galate \\ ${ }^{1}$ Department of Soil Science, Federal Institute of Amapá, Instituto Federal do Amapá (IFAP), Macapá, Brazil \\ ${ }^{2}$ Institute of Agricultural Sciences, Federal Rural University of Amazon, Belém, Brazil \\ ${ }^{3}$ Cyberspace Institute, Federal Rural University of Amazônia, Belém, Brazil \\ Correspondence: J. R. Galvão, Institute of Agricultural Sciences, Federal Rural University of Amazon, Belém, \\ Montese, 2501, 66077-580, Belém, Brazil. Tel: 91-9-8842-1133. E-mail: jessivaldo.galvao@ufra.edu.br
}

Received: March 6, 2018

doi:10.5539/jas.v10n6p146
Accepted: April 7, $2018 \quad$ Online Published: May 15, 2018

URL: https://doi.org/10.5539/jas.v10n6p146

\begin{abstract}
Phosphorus deficiency has been a limiting factor in crop yields due to the low availability of this nutrient in the soil. Thus, the objective of this work was to evaluate the growth and $\mathrm{P}$ concentrations in plant tissue of two cultivars of forage millet grown submitted at doses of phosphorus (P). The experiment was set in greenhouse conditions in a Hapludox. The experiment was carried out in a completely randomized design in a $4 \times 2$ factorial scheme, with four replications, where the factors were the control treatment (without fertilization with P) and three levels of P (50,100 and $200 \mathrm{~kg} \mathrm{ha}^{-1}$ ) as simple superphosphate and two cultivars of pearl millet (BN2 and ADR500). The following were evaluated: plant height, stem diameter, dry matter of the aerial part (DMAP) and roots (DRM), phosphorus content in the leaf, in the stem and in the roots. The interaction between doses of $P$ with the cultivars did not significantly affect the studied variables. Cultivar ADR500 provided greater height, stem diameter and dry matter of the aerial part. The best doses were $166 \mathrm{~kg} \mathrm{ha}^{-1}, 173 \mathrm{~kg}^{-1}, 203 \mathrm{~kg} \mathrm{ha}^{-1}$ and $165 \mathrm{~kg}$ of phosphorus ha ${ }^{-1}$ to height, stem diameter, DMAP, DMR and phosphorus content in the leaf, respectively. The increase of phosphorus rate increased content of $\mathrm{P}$ in the dry matter of the stem and roots on evaluated cultivars.
\end{abstract}

Keywords: soil fertility, phosphated fertilization, forage plant, pearl millet

\section{Introduction}

Tropical humid soils are characterized by the high weathering degree and the low content of available $\mathrm{P}$ to plants (Rocha et al., 2005). In such soils, $P$ is the nutrient that most limits forage production, mainly due to its low mobility and availability, restricting the growth of plants (Costa et al., 2009).

Among the tropical forage, pearl millet (Pennisetum glaucum) is of great importance and represents a high potential of production associated with high quality forage in a short period. Moreover, it is a forage indicated to successive summer crops in Brazilian subtropical and tropical regions as well (Negreiros Neto et al., 2010). The cultivars BN2 and ADR500 are adapted to the production systems of forage and biomass, presenting late cycle and habit of erect growth (EMBRAPA, 2003).

Pearl millet has bromatological composition similar to corn (Gomes et al., 2008), which is an economic alternative due to low production cost during the inter-harvest season. Thus, it is verified that intensification of use of this forage has been increasingly frequent, requiring fertilization in training and maintenance as well (Patês et al., 2007). As for the production potential of this forage, pearl millet can achieve up to $60 \mathrm{tha}^{-1}$ of green mass and 20 tons of dry matter per hectare when grown in early spring (Pedrico et al., 2010).

Soil fertility plays an important role in plant growth, in its productivity and in the nutrient contents in plant tissue (Braz et al., 2004). Therefore, fertilization is an essential practice in the structure and stability of forage plants (Bastos et al., 2008), mainly phosphorus fertilization, whose soils have low availability in this nutrient.

The production potential of a forage plant is genetically determined, however, for achieving such potential, environmental conditions and management must be observed. Among these conditions, the low availability of nutrients such as $\mathrm{P}$ is one of the main factors that affect productivity and the nutritive value of forages. Therefore, when nutrients are not in satisfactory quantities or in some conditions that makes them little available, their 
deficiency in the cells promotes alterations in the plant metabolism (Taiz et al., 2017), reducing their growth as consequence.

In this sense, knowledge of the amount of $\mathrm{P}$ due to the low soil supply capacity and requirements of the crops for this nutrient is essential for allowing the recommendation of the nutrient at the appropriate dose for the growth of plants, according to their requirements. Thus, the objective of this work was to evaluate the growth potential of pearl millet forage cultivars and $\mathrm{P}$ concentrations in plant tissue, grown under phosphate source doses.

\section{Material and Methods}

\subsection{Characterization of Experimental Area}

The experiment was carried out from August to November 2012, in a greenhouse at the Institute of Agricultural Sciences (Instituto de Ciências Agrárias) at Federal Rural University of Amazon (UFRA), in Belém, state of Pará The experimental units were composed of pots with a capacity of $5 \mathrm{dm}^{3}$ of soil, collected in the topsoil $0-20 \mathrm{~cm}$ of a dystrophic Yellow Oxisol (EMBRAPA, 2013), in a remaining forest area of Embrapa Amazônia Oriental $\left(01^{\circ} 41^{\prime} 10^{\prime \prime} \mathrm{S}\right.$ and $\left.48^{\circ} 32^{\prime} 24^{\prime \prime} \mathrm{W}\right)$. According to classification of Köppen (1948), the climate in the area is the Afi, with an average annual temperature of $26^{\circ} \mathrm{C}$ with high rainfall, with an average of $2,754.4 \mathrm{~mm}$ per year, where rainy season is from December to May and a less rainy season is from June to November (Nechet, 1993).

\subsubsection{Characterization of Soil}

After collection, soil was air dried crushed, homonogeneized and sieved through a $2 \mathrm{~mm}$ stainless steel mesh sieve. After that, three compound samples were taken, formed from six simple samples. The physical and chemical characteristics of the soil were as follows: $\mathrm{pH}\left(\mathrm{H}_{2} \mathrm{O}\right): 4.1 ; \mathrm{Ca}^{2+}: 0.1 \mathrm{cmol}_{\mathrm{c}} \mathrm{dm}^{-3} ; \mathrm{Mg}^{2+}: 0.2 \mathrm{cmol}_{\mathrm{c}} \mathrm{dm}^{-3}$; $\mathrm{Al}^{3+}: 2.1 \mathrm{cmol}_{\mathrm{c}} \mathrm{dm}^{-3} ; \mathrm{H}^{+}+\mathrm{Al}^{3+}: 9.2 \mathrm{cmol}_{\mathrm{c}} \mathrm{dm}^{-3} ; \mathrm{K}^{+}: 0.05 \mathrm{mg} \mathrm{dm}{ }^{-3} ; \mathrm{P}: 6.7 \mathrm{mg} \mathrm{dm}^{-3}$; Corrected: $15.6 \mathrm{~g} \mathrm{~kg}^{-1}$, Clay $130 \mathrm{~g} \mathrm{~kg}^{-1}$, silt $120 \mathrm{~g} \mathrm{~kg}^{-1}$ and sand $750 \mathrm{~g} \mathrm{~kg}^{-1}$. Chemical characteristics were determined according to Embrapa (1997) and particle size was classified according to Gee and Bauder (1986).

\subsection{Experimental Design}

The experimental design was complete randomized in a $4 \times 2$ factor scheme, where the factors were the application of varying rate of $P$ at $0,50,100$ and $200 \mathrm{~kg} \mathrm{ha}^{-1}$, corresponding to $0.0,0.291,0.581$ and $1.163 \mathrm{~g}$ of simple superphosphate plot $^{-1}$ and two pear millet cultivars (BN2 and ADR500), with four replications, totaling 32 experimental plots.

Soil acidity was corrected 30 days before pearl millet sowing, using $6.25 \mathrm{tha}^{-1}$ of dolomitic limestone with $32 \%$ of $\mathrm{CaO}, 15 \%$ of $\mathrm{MgO}$ and PRNT of $91 \%$, to rise base saturation by $60 \%$ (Raij et al., 1997). Basic fertilization with macro and micro nutrients was performed at sowing using $200 \mathrm{mg}$ of $\mathrm{N}, 500 \mathrm{mg}$ of K; $5 \mathrm{mg}$ of $\mathrm{Zn} ; 1.5 \mathrm{mg}$ of $\mathrm{Cu} ; 0.5 \mathrm{mg}$ of $\mathrm{B}$ and $0.1 \mathrm{mg}$ of Mo per $\mathrm{dm}^{3}$ of soil as urea, $\mathrm{KCl}, \mathrm{ZnCl}_{2}, \mathrm{CuCl}_{2} \cdot 2 \mathrm{H}_{2} \mathrm{O}, \mathrm{H}_{3} \mathrm{BO}_{3}$ and $\left(\mathrm{NH}_{4}\right)$ $6 \mathrm{Mo}_{7} \mathrm{O}_{24} \cdot 4 \mathrm{H}_{2} \mathrm{O}$, respectively according to recommendation proposed by Embrapa (2003) and Malavolta (1980).

Fifteen seeds were sown per pot, keeping two plants after thinning, held 10 days after emergence (DAE). During the experiment the humidity was maintained at $60 \%$ of the total pore volume.

\subsection{Data Collection}

To evaluate the vegetative cycle of pear millet, biometric data were collected 70 days after sowing, using the following variables: stem diameter (using digital calipers), plant height (measured with a tape measure from the plant neck to the final end of the last leaf), panicle length and green mass and dry mass of roots, stems, leaves and panicles.

At 70 DAS, when the grains were in milky soft ${ }^{-1}$ dough stage, pearl millet plants were harvest with division in panicle, stem and leaf. Plant material of the aerial part and roots of the pearl millet were packed in paper bags, weighed to obtain fresh mass and then dried in an oven with forced air circulation at $65-70^{\circ} \mathrm{C}$ for $72 \mathrm{~h}$, until the constant weight. The P content in the leaf, stem and root was extracted by nitric-perchloric digestion and determined by flame spectrophotometer according to the methodology described by Silva (1999).

\subsection{Data Analysis}

The results were submitted to analysis of variance when significant by the $\mathrm{F}$ test. The cultivars were compared by Tukey test $(\mathrm{p}<0.05)$ and the effect of $\mathrm{P}$ doses were analyzed by regression, adjusting the equations to adequately express the behavior of the variables. The values for maximum agronomic efficiency (MAE) of pearl millet cultivars were determined using the first derivative of the functions corresponding to each growth variable, equating them to zero. Furthermore, for the production of dry matter, maximum economic efficiency (MEE) was calculated which was $90 \%$ of MAE (Cruz et al., 2008). 


\section{Results and Discussion}

Doses of $\mathrm{P}$ promoted significant effects in all the analyzed variables. With regard to the cultivars, significant effects were observed only for height, diameter and dry matter of the aerial part. The other variables, that is, root dry matter, phosphorus content in the leaves, phosphorus content in the stem and phosphorus content in the roots were not significantly affected. The interaction between doses of $\mathrm{P}$ with the cultivars did not significantly affect the studied variables (Table 1).

Table 1. Summary of the analysis of variance for the variables plant height, stem diameter, dry matter of the aerial part (DMAP), dry matter of the roots (DRM), and content of phosphorus in the leaf (PCL), in the stem (PCS) and in the roots (PCR) of pearl millet cultivars according to the phosphate fertilization

\begin{tabular}{lllllllll}
\hline \multirow{2}{*}{ Source of variation } & \multirow{2}{*}{ D.F. } & \multicolumn{7}{c}{ Mean Square } \\
\cline { 3 - 8 } & & Height & Diameter & DMAP & DRM & PCL & PCS & PCR \\
\hline Doses of (P) & 3 & $9193.886^{* *}$ & $40.577^{* *}$ & $237.660^{* *}$ & $6.682^{* *}$ & $0.133^{* *}$ & $1.115^{* *}$ & $1.043^{* *}$ \\
Cultivars (C) & 1 & $349.470^{*}$ & $5.703^{*}$ & $10.237^{*}$ & $0.374^{\mathrm{NS}}$ & $0.031^{\mathrm{NS}}$ & $0.022^{\mathrm{NS}}$ & $0.033^{\mathrm{NS}}$ \\
$\mathrm{P} \times \mathrm{C}$ & 3 & $12.073^{\mathrm{NS}}$ & $0.053^{\mathrm{NS}}$ & $0.715^{\mathrm{NS}}$ & $0.012^{\mathrm{NS}}$ & $0.000^{\mathrm{NS}}$ & $0.001^{\mathrm{NS}}$ & $0.001^{\mathrm{NS}}$ \\
\hline $\mathrm{CV}(\%)$ & - & 7.27 & 10.24 & 11.18 & 24.65 & 5.18 & 6.03 & 9.83 \\
\hline
\end{tabular}

Note. $\mathrm{CV}=$ coefficient of variation; ${ }^{\mathrm{NS}}=$ not significant, ${ }^{*}=$ significant $(p<0.005) ; * *=$ significant $(p<0.01)$ by the Tukey test.

\subsection{Biometric Variables}

Application of $\mathrm{P}$ doses promoted an increase with a quadratic adjustment in relation to the height and diameter of the stem in the millet cultivars (Figure 1). The greatest height $(126 \mathrm{~cm})$ was achieved at the dose of $166 \mathrm{~kg} \mathrm{ha}^{-1}$ (Figure 1a). In relation to the diameter, the highest value $\left(11.4 \mathrm{~mm}\right.$ ) was found at the dose of $173 \mathrm{~kg} \mathrm{ha}^{-1}$ (Figure 1b). This increase in height and diameter may be related to the function of the element and its importance in the plant mineral nutrition, among others, to perform structural function in the plant (Malavolta et al., 1997). Phosphorus is essential for nucleic acid synthesis, membrane development and stability, energy metabolism during the production of photoassimilates and other physiological processes relevant to plant growth (Hasan et al., 2016).

When working in a greenhouse with doses of 50, 100 and $150 \mathrm{~kg} \mathrm{ha}^{-1} \mathrm{P}$, Belarmino et al. (2003) found an increase in the height of Tanzania grass (Panicum maximum). In an experiment with corn with doses of 60, 120, 180 and $240 \mathrm{~kg} \mathrm{ha}^{-1}$ in field conditions, Lucena et al. (2000) achieved greater plant heights as phosphate fertilization was increased.

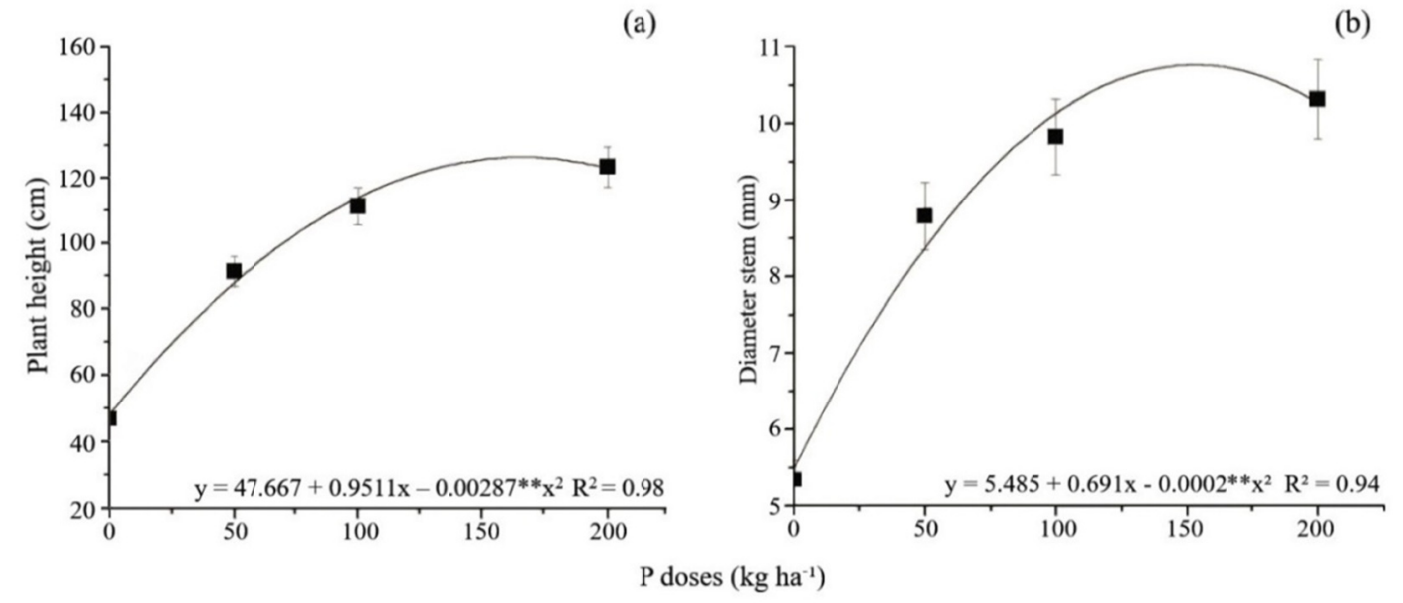

Figure 1. Effect of varying rate of phosphorus on the plant height (Figure a) and stem diameter (Figure b) of pearl millet

Note. Vertical bars at each dot are the standard error of the means. **Significant $(p<0.01)$ by the $t$ test. 
In relation to the cultivars, ADR500 presented the highest growth with average height and diameter of $96.52 \mathrm{~cm}$ and $8.99 \mathrm{~mm}$, respectively, which is higher than cultivar BN2, which reached a height of $89.91 \mathrm{~cm}$ and diameter of $8.15 \mathrm{~mm}$ (Figures 2a and 2b). Working with Xaraés grass (Brachiaria brizantha), in field conditions, Alencar et al. (2009) found higher plant heights, with values ranging from 40 to $71 \mathrm{~cm}$.

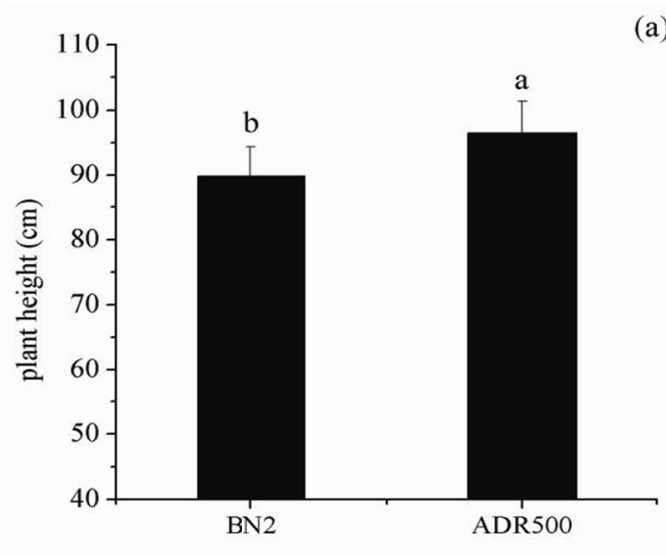

(a)

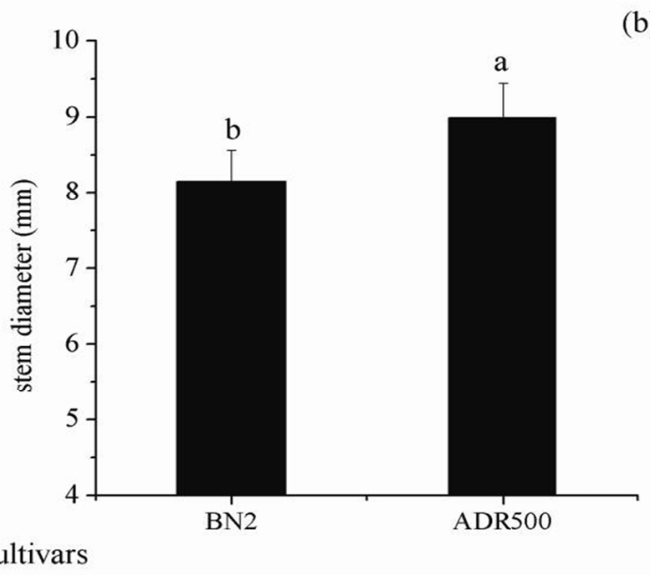

(b)

Figure 2. Plant height (Figure a) and stem diameter (Figure b) of pearl millet cultivars

Note. Vertical bars are the standard error of the mean. Different letters point to significant difference by the test of Tukey $(p<0.05)$.

A quadratic behavior was observed in the dry matter production of the aerial part and roots of pearl millet with the applied doses of phosphorus (Figure 3). The maximum efficiency production of DMAP was $17 \mathrm{~g}^{-1 a n t^{-1}}$ at the dose of $203 \mathrm{~kg} \mathrm{ha}^{-1}$ of $\mathrm{P}$ (Figure 3a). For the production of RDM, the highest value was $2.9 \mathrm{~g} \mathrm{plant}^{-1}$, reached at the dose of $165 \mathrm{~kg} \mathrm{ha}^{-1}$ of P (Figure 3b), and the production corresponding to $90 \%$ of the maximum for DMAP and RDM were 15 and $2.6 \mathrm{~g}^{\text {plant }}{ }^{-1}$, respectively.

Phosphorus provides greater plant growth and helps the respiration and absorption of ions (Marschner, 1993). Therefore, an adequate supply of this nutrient promotes respiration of the root system, increasing plant growth. Patês et al. (2007) also found increase in the dry matter for pearl millet, when studying the doses of 20,40,80, 160,320 and $640 \mathrm{~kg} \mathrm{ha}^{-1} \mathrm{P}$ on greenhouse.

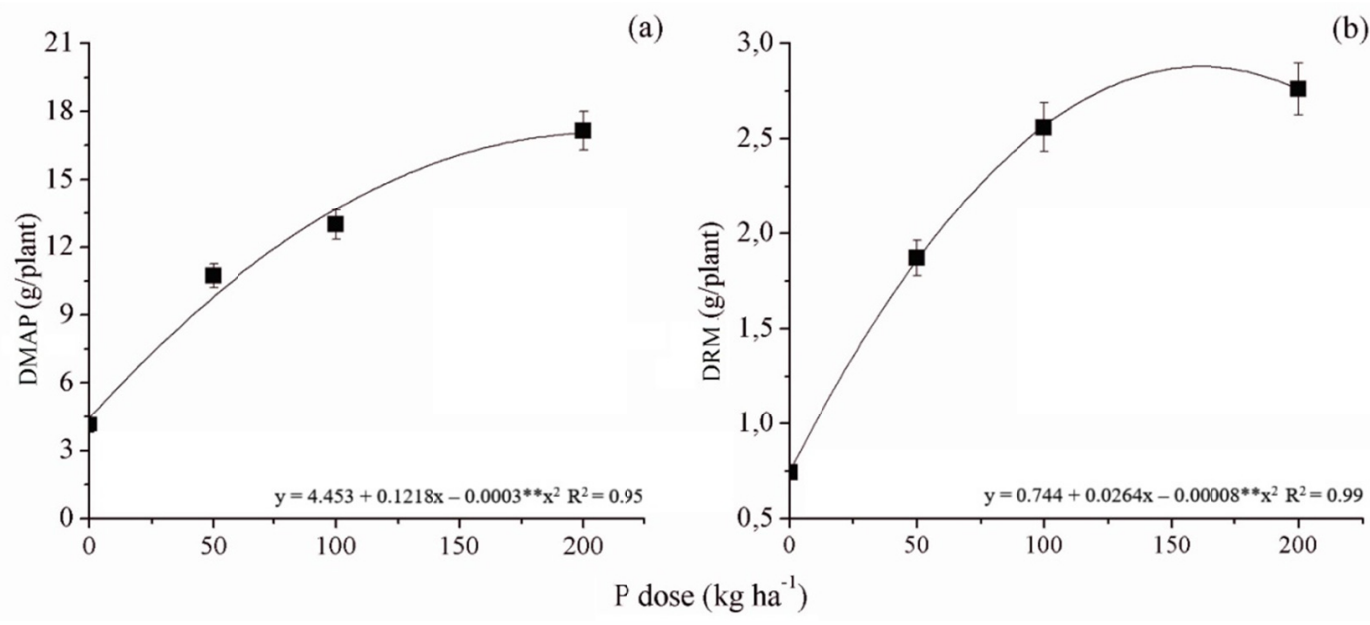

Figure 3. Effect of varying rate of phosphorus on the dry matter of the aerial part (DMAP) (Figure a) and root dry matter (DRM) (Figure b) of pearl millet

Note. Vertical bar at each dot is the standard error of the mean. ${ }^{* *}$ Significant $(p<0.01)$ by the $t$ test. 
Dry matter production varied $(p<0.05)$ among cultivars. Cultivar ADR500 had the highest production with $11.81 \mathrm{~g} \mathrm{plant}^{-1}$ of DMAP (Figure 4). Similar to the results found by Silva et al. (2014) when working in Oxisol with cultivars ADR-7010, BRS-1505 and ADR-500, under field conditions with simple superphosphate and thermo phosphate fertilization, where ADR-7010 showed the highest dry matter production of the aerial part.

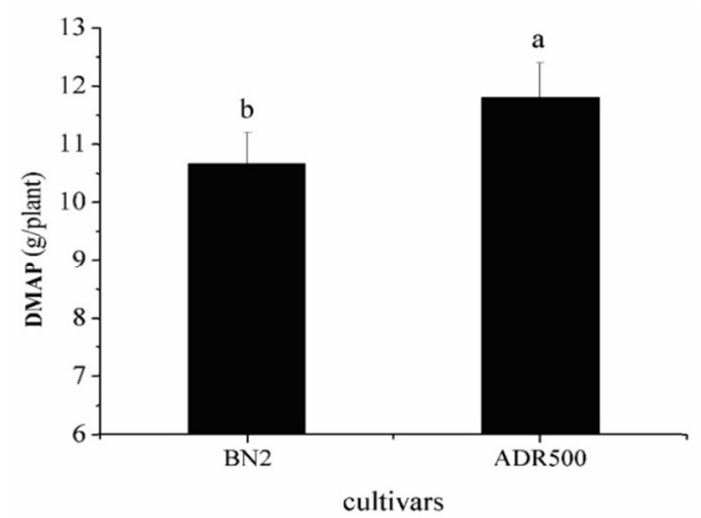

Figure 4. Dry matter of the aerial part of pearl millet cultivars

Note. Vertical bars represent the standard errors of the means. Different letters point to a significant difference by the test of Tukey $(p<0.05)$.

In the leaves, $\mathrm{P}$ content presented quadratic behavior at the dose of $125 \mathrm{~kg}$ of P ha ${ }^{-1}$, for a content of $2.10 \mathrm{~g} \mathrm{~kg}^{-1}$ (Figure 5a). Thus, it can be inferred that a dilution effect occurred since dry matter production increased up to the highest dose of $\mathrm{P}$.

\subsection{P content}

It was found in the stem an increasing linear behavior, that is, content of $\mathrm{P}$ increased in the stem as the doses of $\mathrm{P}$ were increased (Figure 5b). It was found that content of $\mathrm{P}$ found in the leaf and stem were close to the levels reported by Prado and Vidal (2008), who obtained $3.3 \mathrm{~g} \mathrm{~kg}^{-1}$. Braz et al. (2002) reported that in established Brachiaria decumbens, $\mathrm{P}$ showed an average content of $1.4 \mathrm{~g} \mathrm{~kg}^{-1}$ in the aerial part of the plant.

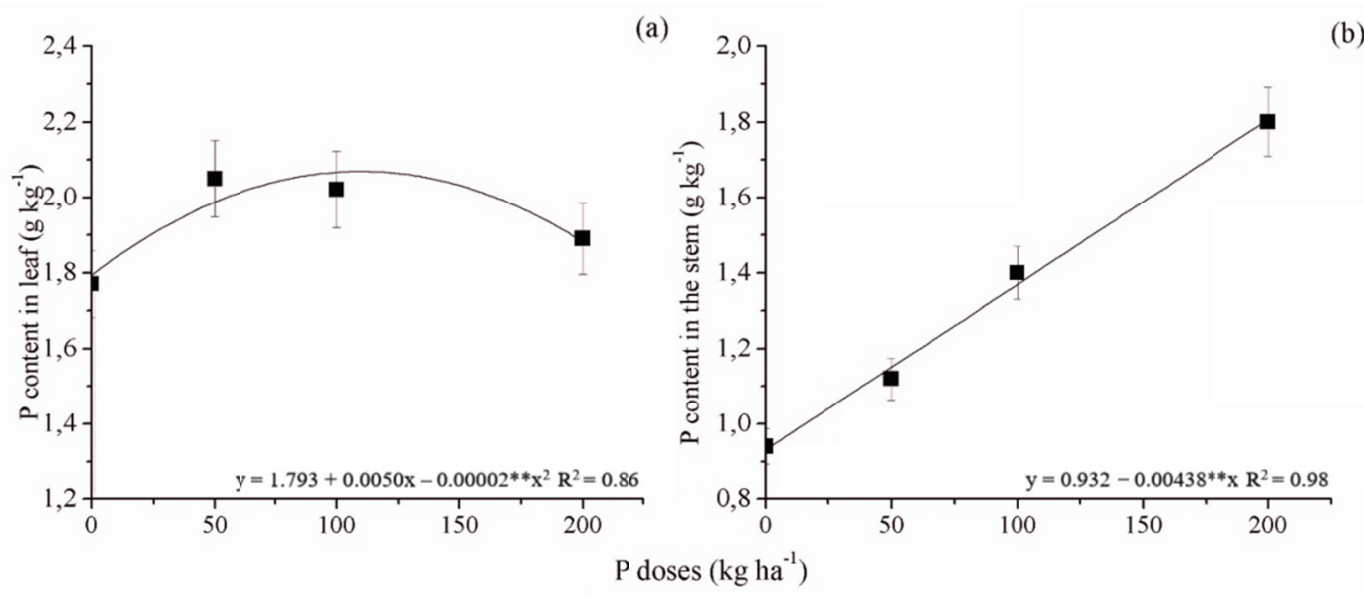

Figure 5. Effect of varying rate of phosphorus on the content of $\mathrm{P}$ in the leaf (Figure a) and stem (Figure b) of forage pearl millet

Note. Vertical bars at each dot represent standard errors of the means. **Significant $(p<0.01)$ by the $t$ test. 
Regarding the content of $\mathrm{P}$ in the roots, it was observed that by adding phosphate fertilization, an increase of content of $P$ occurred with the doses of $P$, presenting $1.6 \mathrm{~g} \mathrm{~kg}^{-1}$ with the maximum dose of $200 \mathrm{~kg} \mathrm{ha}^{-1}$ of $\mathrm{P}$ (Figure 6). This result suggests that the evaluated cultivars have a high accumulation of available $\mathrm{P}$ in the stem and in the roots, thus the applied doses did not promote the maximum accumulation by the plants.

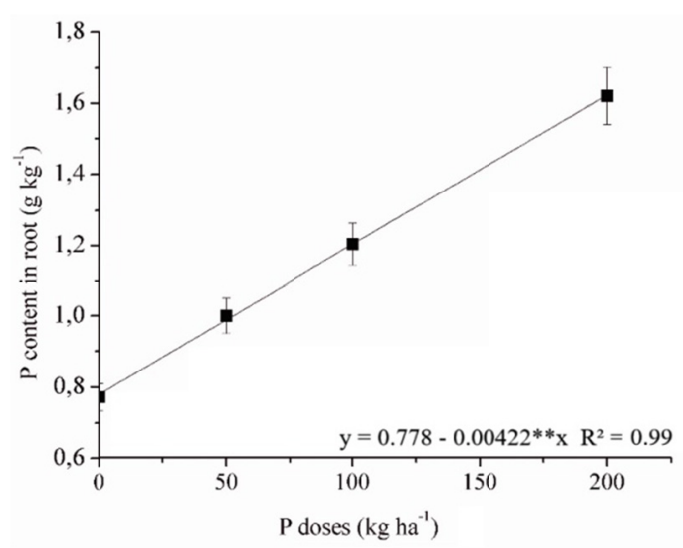

Figure 6. Effect of varying rate of phosphorus on the content of $\mathrm{P}$ in the roots of forage pearl millet

Note. Vertical bars at each dot represent standard error of the mean. **Significant $(p<0.01)$ by the $t$ test.

According to Hasan et al. (2016), the plant root system architecture significantly alters due to nutrient availability on soil. The optimal content of $\mathrm{P}$ for growth of a crop is $0.3-0.5 \%\left(3-5 \mathrm{~g} \mathrm{~kg}^{-1}\right)$, but these values may vary depending on the crop and other external factors (PRADO; VIDAL, 2008). Corrêa and Haag (1993) observed that the critical level of P for Panicum maximum was $1.0 \mathrm{~g} \mathrm{~kg}^{-1}$ in plants grown in Oxisol. However, Hoffmann et al. (1995) observed critical level of $P$ to Colonião grass, equal to $1.8 \mathrm{~g} \mathrm{~kg}^{-1}$. The content of $\mathrm{P}$ in pearl millet presented values within the range observed for forage plants in the literature.

Phosphorus together with nitrogen is the most readily redistributed element in the plant, according to Malavolta et al. (1997). The senescence of older leaves in pearl millet also influenced the reduction in the content of $\mathrm{P}$ in the final stages, despite the high mobility of $\mathrm{P}$; only $60 \%$ of the phosphorus contained in the older leaves is translocated to the younger plant organs (Mercante et al., 2011).

\section{Conclusions}

Height, diameter and dry matter of the aerial part and roots of pearl millet increase as phosphate fertilization is incremented.

Cultivar ADR 500 presented the highest height, stem diameter and dry matter of the aerial part.

The best doses were $166 \mathrm{~kg} \mathrm{ha}^{-1}, 173 \mathrm{~kg}^{-1}, 203 \mathrm{~kg} \mathrm{ha}^{-1}$ and $165 \mathrm{~kg}_{\text {of }}$ phosphorus ha ${ }^{-1}$ to height, stem diameter, DMAP, DRM and phosphorus content in the leaf, respectively.

The increase of phosphate fertilization promotes the increase in the content of $\mathrm{P}$ in the dry matter of stems and roots.

\section{Acknowledgements}

To CNPq (National Council for Scientific and Technological Development) for the financial support, for granting the scholarship of the first author and second author productivity scholarships.

\section{References}

Alencar, C. A. B., Oliveira, R. A., Cóser, A. C., Martins, C. E., Cunha, F. F., Figueiredo, J. L. A., ... Cecon, P. R. (2009). Cobertura do solo e altura de capins cultivados sob pastejo com distintas lâminas de irrigação e estações anuais. Bioscience Journal, 25, 113-121.

Bastos, A. L., Costa, J. P. V., Silva, I. F., Raposo, R. W. C., \& Souto, J. S. (2008). Influência de doses de fósforo no fluxo difusivo em solos de Alagoas. Revista Brasileira de Engenharia Agrícola e Ambiental, 12(2), 136-142. https://doi.org/10.1590/S1415-43662008000200005 
Belarmino, M. C. J., Pinto, J. C., Rocha, G. P., Furtini Neto, A. E., \& Morais, A. R. (2003). Altura de perfilho e rendimento de matéria seca de capim tanzânia em função de diferentes doses de superfosfato simples e sulfato de amônio. Ciência e Agrotecnologia, 27(4), 879-885. https://doi.org/10.1590/S1413-70542003000 400021

Braz, A. J. B. P., Silveira, P. M. da, Kliemann, H. J., \& Zimmermann, F. J. P. (2004). Acumulação de nutrientes em folhas de milheto e dos capins braquiária e mombaça. Pesquisa Agropecuária Tropical, 34(2), 83-87.

Braz, S. P., Nascimento Júnior, D., Cantarutti, R. B., Reagazzi, A. J., Martins, C. E., Fonseca, D. M., \& Barbosa, R. A. (2002). Aspectos quantitativos do processo de reciclagem de nutrientes pelas fezes de bovinos sob pastejo em pastagem de Brachiaria decumbens na Zona da Mata de Minas Gerais. Revista Brasileira de Zootecnia, 31(2), 858-865. https://doi.org/10.1590/S1516-35982002000400008

Corrêa, L. A., \& Haag, H. P. (1993). Níveis críticos de fósforo para o estabelecimento de gramíneas forrageiras em Latossolo Vermelho-Amarelo, álico. I: ensaio em casa de vegetação. Scientia Agricola, 50, 99-108. https://doi.org/10.1590/S0103-90161993000100014

Costa, J. P. V., Bastos, A. L., Reis, L. S., Martins, G. O., \& Santos, A. F. (2009). Difusão de fósforo em solos de Alagoas influenciada por fontes do elemento e pela umidade. Revista Caatinga, 22(3), 229-235.

Cruz, S. C. S., Pereira, F. R. da S., Santos, J. R., Albuquerque, A. W. de, \& Pereira, R. G. (2008). Adubação nitrogenada para o milho cultivado em sistema plantio direto, no Estado de Alagoas. Revista Brasileira de Engenharia Agrícola Ambiental, 12, 62-68. https://doi.org/10.1590/S1415-43662008000100009

EMBRAPA (Empresa Brasileira de Pesquisa Agropecuária). (2003). Manejo da Cultura do Milheto. Sete Lagoas, MG: Embrapa Milho e Sorgo, Centro Nacional de Pesquisa de Solos.

EMBRAPA (Empresa Brasileira de Pesquisa Agropecuária). (1997). Manual de métodos de análise de solo (2nd ed). Rio de Janeiro, RJ: Embrapa, Centro Nacional de Pesquisa de Solos.

EMBRAPA (Empresa Brasileira de Pesquisa Agropecuária). (2013). Sistema Brasileiro de Classificação de Solos (3rd ed.). Brasília: Embrapa Produção de Informação, Centro Nacional de Pesquisa de Solos.

Gee, G. W., \& Bauder, J. W. (1986). Particle-size analysis. In A. Klute (Ed.), Methods of soil analysis. Part 1. Physical and mineralogical methods (2nd ed). Madison, American Society of Agronomy, Soil Science Society of America.

Gomes, C. G., Rodrigues, M. P., Albino, L. F. T., Rostangno, H. S., Gomes, M. F. M., Mello, H. H. C., \& Brumano, G. (2008). Determinação da composição química e energética do milheto e sua utilização em rações para frangos de corte de 1 a 21 dias de idade. Revista Brasileira de Zootecnia, 37(9), 1617-1621. https://doi.org/10.1590/S1516-35982008000900013

Hasan, M. M., Hasan, M. M., Teixeira da Silva, J. A., \& Li, X. (2016). Regulation of phosphorus uptake and utilization: Transitioning from current knowledge to practical strategies. Cellular \& Molecular Biology Letters, 21, 7. https://doi.org/10.1186/s11658-016-0008-y

Hoffmann, C. R., Faquin, V., Guedes, G. A. A., \& Evangelista, A. R. (1995). O nitrogênio e o fósforo no crescimento da braquiária e do colonião em amostras de um Latossolo da região Noroeste do Paraná. Revista Brasileira de Ciência do Solo, 19, 79-86.

Köppen, W. (1948). Climatologia. México: Ed. Fundo de Cultura Econômica.

Lucena, L. F. C., Oliveira, F. A., Silva, I. F., \& Andrade, A. P. (2000). Resposta do milho a diferentes dosagens de nitrogênio e fósforo aplicados ao solo. Revista Brasileira de Engenharia Agrícola e Ambiental, 4(3), 334-337. https://doi.org/10.1590/S1415-43662000000300005

Malavolta, E. (1980). Elementos de nutrição mineral de plantas. São Paulo, Agronômica Ceres.

Malavolta, E., Vitti, G. C., \& Olveira, S. A. de. (1997). Avaliação do estado nutricional das plantas: Princípios e aplicações (2nd ed.). Piracicaba, SP: Potafos.

Marschner, H. (1993). Mineral nutrition of higher plants (2nd ed.). San Diego.

Mercante, N. C., Camacho, M. A., \& Paredes, F. P. J. (2011). Teores de nutrientes no milheto como cobertura de solo. Bioscience Journal, 27(2), 196-204.

Nechet, D. (1993). Análise da Precipitação em Belém de 1896 a 1991. Boletim de Geografia Teorética, 23(45-46), 150-156. 
Negreiros Neto, J. V., Santos, A. C., Leite, R. L. L., \& Cruz, R. S. (2010). Análise de diferentes doses de nitrogênio e espaçamento em milheto no norte do Tocantins. Biotemas, 23(4), 19-23. https://doi.org/ $10.5007 / 2175-7925.2010 \mathrm{v} 23 \mathrm{n} 4 \mathrm{p} 19$

Patês, N. M. S., Pires, A. J. V., Silva, C. C. F., Santos, L. C., Carvalho, G. G. P., \& Freire, M. A. L. (2007). Características morfogênicas e estruturais do capim-tanzânia submetido a doses de fósforo e nitrogênio. Revista Brasileira de Zootecnia, 36(6), 1736-1741. https://doi.org/10.1590/S1516-35982007000800005

Pedrico, A., Santos, A. C., Machado, L. A. R., Negreiros Neto, J. V., \& Gomes, A. M. N. (2010). Desenvolvimento e produtividade do milheto em função de diferentes espaçamentos e níveis de fósforo na região norte do Estado do Tocantins. Amazônia: Ciência \& Desenvolvimento, 5(10), 143-152.

Prado, R. de M., \& Vidal, A. A. (2008). Efeitos da omissão de macronutrientes em solução nutritiva sobre o crescimento e a nutrição do milheto. Pesquisa Agropecuária Tropical, 38(3), 208-214.

Raij, B. van, Cantarella, H., Quaggio, J. A., \& Furlani, A. M. C. (1997). Recomendações de adubação e calagem para o Estado de São Paulo (2nd ed.). Campinas, Instituto Agronômico de Campinas.

Rocha, A. T., Duda, G. P., Nascimento, C. W. A., \& Ribeiro, M. R. (2005). Fracionamento de fósforo e avaliação de extratores de P disponível em solos da ilha de Fernando de Noronha. Revista Brasileira de Engenharia Agricola e Ambiental, 9(2), 178-184. https://doi.org/10.1590/S1415-43662005000200005

Silva, A. G, França, A. F. S., Miyagi, E. S., Dambros, C. E., \& Lopes, F. B. (2014). Eficiência da fertilização fosfatada e nitrogenada em cultivares de milheto. Ciência Animal Brasileira, 15(2), 119-127. https://doi.org/10.1590/1809-6891v15i29010

Silva, F. C. da. (1999). Manual de análises químicas de solos, plantas e fertilizantes. Rio de Janeiro: Embrapa Solos.

Taiz, L., Zeiger, E., Moller, I., \& Murphy, A. (2017). Fisiologia e desenvolvimento vegetal (6th ed.). Porto Alegre: Artmed.

\section{Copyrights}

Copyright for this article is retained by the author(s), with first publication rights granted to the journal.

This is an open-access article distributed under the terms and conditions of the Creative Commons Attribution license (http://creativecommons.org/licenses/by/4.0/). 